\title{
Pola Pengobatan, Pengetahuan, Dan Perilaku Swamedikasi Acne Vulgaris Di Kalangan Remaja Kabupaten Pekalongan Tahun 2021
}

\author{
Sulistiyani ${ }^{1}$, Ainun Muthoharoh ${ }^{2 *}$,Wulan Agustin Ningrum ${ }^{3}$, St. Rahmatullah ${ }^{4}$ \\ 1,2,3,4Program Studi Sarjana Farmasi, Fakultas Ilmu Keshatan, Universitas Muhammadiyah \\ Pekajangan Pekalongan \\ *email:ainun.muthoharoh@gmail.com
}

\begin{abstract}
In general, acne vulgaris begins at the age of 12-15 years with a peak severity at the age of 17-21 years. Acne vulgaris is the most common disease in adolescence. Acne vulgaris is mostly in adolescents aged 13-17 years in Pekalongan Regency. The purpose of this study was to determine the pattern of treatment, knowledge and behavior of acne vulgaris selfmedication carried out by adolescents in Pekalongan Regency in 2021. This study was a cross sectional study with an instrument in the form of a questionnaire. The sample in this study were teenagers in Pekalongan Regency. The sampling technique was done by quota sampling, this survey was followed by 396 respondents with an age range of 12-19 years. Data analysis in this study using the Chi-square. The results of this study indicate that the pattern of treatment in adolescents in Pekalongan Regency is sufficient, namely $58.78 \%$, the level of knowledge of the respondents is sufficient as much as $64.1 \%$ while the results in the behavioral category of respondents are $66.4 \%$. The results of the correlation analysis test showed that there was a relationship between the level of knowledge on the acne vulgaris treatment pattern with a significance value of 0.000 , there was a relationship between the treatment pattern on the acne vulgaris self-medication behavior with a significance value of 0.000 and there was a relationship between the level of knowledge on the acne vulgaris selfmedication behavior with a significance value of 0.000 .
\end{abstract}

Keywords: acne vulgaris, adolescence, knowledge, behavior

\begin{abstract}
Abstrak
Pada umumnya acne vulgaris mulai pada usia 12-15 tahun dengan puncak tingkat keparahan pada umur 17-21 tahun. Acne vulgaris merupakan penyakit terbanyak pada masa remaja. Acne vulgaris terbanyak pada masa remaja berusia 13-17 tahun di Kabupaten Pekalongan. Tujuan dari penelitian ini adalah untuk mengetahui pola pengobatan, pengetahuan dan perilaku swamedikasi acne vulgaris yang dilakukan oleh kalangan remaja di Kabupaten Pekalongan tahun 2021. Penelitian ini merupakan penelitian cross sectional dengan instrumen berupa kuesioner. Sampel pada penelitian ini adalah kalangan remaja di Kabupaten Pekalongan. Teknik pengambilan sampel dilakukan secara kuota sampling, survei ini diikuti oleh 396 respoden dengan rentang usia 12-19 tahun. Analisis data pada penelitian ini menggunakan teknik pengujian Chi-square. Hasil penelitian ini menunjukan pola pengobatan pada remaja di Kabupaten Pekalongan ialah cukup yaitu sebanyak 58,78\%, tingkat pengetahuan responden ialah cukup sebanyak $64,1 \%$ sedangkan hasil pada kategori perilaku responden ialah $66,4 \%$. Hasil uji analisis korelasi terdapat hubungan antara tingkat pengetahuan terhadap pola pengobatan acne vulgaris dengan nilai signifikasi 0,000 , terdapat hubungan antara pola pengobatan terhadap perilaku swamedikasi acne vulgaris dengan nilai signifikasi 0,000 dan terdapat hubungan antara tingkat pengetahuan terhadap perilaku swamedikasi acne vulgaris dengan nilai signifikasi 0,000 .
\end{abstract}

Kata kunci: acne vulgaris, remaja, pengetahuan, perilaku 


\section{Prosiding Seminar Nasional Kesehatan 2021 Lembaga Penelitian dan Pengabdian Masyarakat Universitas Muhammadiyah Pekajangan Pekalongan}

\section{Pendahuluan}

Acne vulgaris (jerawat) adalah penyakit kulit akibat peradangan kronis dengan patogenesis kompleks, yang dapat melibatkan kelenjar sebasea, hiperkeratinisasi folikur, kolonisasi bakteri berlebihan, reaksi imun tubuh, dan peradangan [4]. Pemicu timbulnya jerawat antara lain genetik, aktivitas hormonal pada siklus menstruasi, stres, aktivitas kelenjar sebasea yang hiperaktif, kebersihan, makanan, dan penggunaan kosmetik. Jerawat disebabkan oleh penyumbatan pori kulit sehingga sekresi minyak menjadi terhambat kemudian membesar dan mengering menjadi jerawat [5].

Pada umumnya acne vulgaris mulai pada usia 12-15 tahun, dengan puncak tingkat keparahan pada umur 17-21 tahun. Acne vulgaris adalah penyakit terbanyak pada masa remaja usia 15-18 tahun [3]. Pravelensi insidensi acne vulgaris tertinggi di Indonesia terdapat pada perempuan antara usia 14 sampai 17 tahun berkisar $83-85 \%$ dan pada laki-laki antara usia 16 sampai 19 tahun berkisar 95-100\%, tetapi acne vulgaris juga bisa terjadi pada usia 30-40 tahun dan penyakit ini dapat menetap pada usia lanjut.

Hasil dari studi pendahuluan yang dilakukan di Kabupaten Pekalongan pada bulan Desember di beberapa kecamatan yang ada di Kabupaten Pekalongan yaitu Kecamatan Kajen, Kesesi, Sragi, Bojong, Wonopringgo, Kedungwuni, Tirto, Wiradesa dan Wonokerto bahwa penyakit acne vulgaris pada umumnya dialami pada remaja usia 1317 tahun. Pola pengobatan yang dilakukan kalangan remaja Kabupaten Pekalongan sebagian besar yaitu melalukan swamedikasi dengan membeli obat krim antiacne di apotek serta menggunakan masker, serum dan remaja lainnya memilih untuk membiarkan jerawat.

Terapi non farmakologi jerawat yaitu mencuci wajah secara tepat, tidak memencet jerawat, hindari stress, memperbaiki pola makan dan gaya hidup. Adapun terapi farmakologi swamedikasi jerawat yaitu menggunakan obat-obatan seperti Benzoil peroksida, sulfur dan asam salisilat. Benzoil peroksida merupakan salah satu obat golongan antimikroba non antibiotik. Mekanisme kerja benzoil peroksida dapat diuraikan oleh sistem pada kulit sehingga dapat membebaskan radikal bebas oksigen yang akan mengoksida protein bakteri. Asam salisilat dan sulfur juga sebagai anti jerawat termasuk kedalam golongan peeling agen. Asam salisilat dapat menghilangkan kovalen lipid interselular yang berikatan dengan cornified envelope di sekitar keratinosit (agen keratolitik) [1].

Swamedikasi dapat diartikan sebagai kegiatan untuk mengobati suatu penyakit maupun gejala yang ringan dan obat yang digunakan tanpa resep dokter. Menurut WHO swamedikasi merupakan pemilihan obat yang tanpa resep dari dokter oleh seseorang yang digunakan untuk mengobati gejala atau penyakit yang sudah diketahuinya. Swamedikasi dilakukan oleh masyarakat untuk menghemat biaya pengobatan. Namun, didalam praktiknya kesalahan melakukan swamedikasi dapat terjadi karena terbatasnya sumber pengetahuan dari masyarakat mengenai jenis obat yang akan digunakan [2]. 


\section{Prosiding Seminar Nasional Kesehatan Lembaga Penelitian dan Pengabdian Masyarakat Universitas Muhammadiyah Pekajangan Pekalongan

\section{Metode}

Penelitian ini merupakan penelitian cross sectional dengan pengambilan data menggunakan alat ukur kuesioner. Teknik pengambilan sampel menggunakan kuota sampling dimana sampel dihitung menggunakan rumus slovin [8]. Populasi dalam penelitan ini adalah kalangan remaja di Kabupaten Pekalongan yang pernah mengalami atau sedang mengalami acne vulgaris. Populasi penelitan ini sebanyak 83.007 berdasarkan rumus slovin didapatkan 396 remaja yang memenuhi kriteria inklusi.

Penelitian dilakukan dalam bentuk survei, menggunakan teknik non probability sampling dengan metode kuota sampling dan pendekatan cross sectional. Pada penelitin ini populasi yang akan digunakan yaitu kalangan remaja di Kabupaten Pekalongan yang akan diambil sebagai subjek penelitian. Penentuan sampel dipilih sesuai kuota sampling yaiu penetapan subjek berdasarkan kapasitas/daya tampung yang diperlukan dalam penelitian sesuai dengan kriteria yang diinginkan [5]. Penelitian ini menggunakan alat bantu berupa kuesioner dengan skala guttman yaitu skala pertanyaan tertutup berupa jawaban "Ya/Tidak", "Benar/Salah". Analisa yang digunakan untuk melihat hubungan antar variabel dengan menggunakan uji statistic Chi-square.

\section{Hasil dan Pembahasan}

\section{Hasil}

Hasil gambaran Pola pengobatan responden terhadap acne vulgaris di Kabupaten Pekalongan

Tabel 1. Persentase Pola Pengobatan dari Responden

\begin{tabular}{ccc}
\hline Katagori & Frekuensi & $\begin{array}{c}\text { Persentase } \\
(\%)\end{array}$ \\
\hline Baik & 137 & 34,6 \\
\hline Cukup & 233 & 58,8 \\
\hline Kurang & 26 & 6,6 \\
\hline
\end{tabular}

Hasil gambaran Tingkat Pengetahuan responden terhadap acne vulgaris di Kabupaten Pekalongan

Tabel 2. Persentase Tingkat Pengetahuan dari Responden

\begin{tabular}{ccc}
\hline Katagori & Frekuensi & $\begin{array}{c}\text { Persentase } \\
(\%)\end{array}$ \\
\hline Baik & 106 & 26,8 \\
Cukup & 254 & 64,1 \\
Kurang & 36 & 9,1 \\
\hline Total & 396 & 100 \\
\hline
\end{tabular}




\section{Prosiding Seminar Nasional Kesehatan \\ Lembaga Penelitian dan Pengabdian Masyarakat Universitas Muhammadiyah Pekajangan Pekalongan}

Hasil gambaran perilaku responden terhadap acne vulgaris di Kabupaten Pekalongan

Tabel 3 Persentase Perilaku dari Responden

\begin{tabular}{ccc}
\hline Katagori & Frekuensi & $\begin{array}{c}\text { Persentase } \\
(\%)\end{array}$ \\
\hline Baik & 92 & 23,2 \\
Cukup & 263 & 66,4 \\
Kurang & 41 & 10,4 \\
\hline Total & 396 & 100 \\
\hline
\end{tabular}

Tabel 4 Hasil Uji Statistik Hubungan Tingkat Pengetahuan dengan Pola Pengobatan

\begin{tabular}{ccc}
\hline Korelasi & Konstanta Sig & Nilai Sig \\
\hline $\begin{array}{c}\text { Tingkat pengetahuan } \\
\text { dengan pola } \\
\text { pengobatan }\end{array}$ & $<0,05$ & 0,000 \\
\hline
\end{tabular}

Hubungan Pola Pengobatan Terhadap Perilaku Swamedikasi Acne Vulgaris di Kalangan Remaja Kabupaten Pekalongan

Tabel 5 Hasil Uji Statistik Hubungan Pola Pengobatan dengan Perilaku Swamedikasi

\begin{tabular}{ccc}
\hline Korelasi & Konstanta Sig & Nilai Sig \\
\hline $\begin{array}{c}\text { Pola pengobatan dengan } \\
\text { perilaku swamedikasi }\end{array}$ & $<0,05$ & 0,000 \\
\hline
\end{tabular}

Hubungan Tingkat Pengetahuan Terhadap Perilaku Swamedikasi Acne Vulgaris di Kalangan Remaja Kabupaten Pekalongan

Tabel 6. Hasil Uji Statistik Chi Square Hubungan Tingkat Pengetahuan dengan Perilaku Swamedikasi

\begin{tabular}{ccc}
\hline Korelasi & Konstanta Sig & Nilai Sig \\
\hline $\begin{array}{c}\text { Tingkat pengetahuan } \\
\text { dengan perilaku } \\
\text { swamedikasi }\end{array}$ & $<0,05$ & 0,000 \\
\hline
\end{tabular}

\section{Pembahasan}

Pada penelitian ini berjudul Pola Pengobatan, Pengetahuan, dan Perilaku Swamedikasi Acne Vulgaris di Kalangan Remaja Kabupaten Pekalongan Tahun 2021 yang bertujuan untuk mengetahui bagaimana pola pengobatan, pengetahuan, dan perilaku swamediasi acne vulgaris yang dilakukan oleh kalangan remaja dan mengetahui apakah ada hubungan antara tingkat pengetahuan terhadap pola pengobatan dan perilaku swamedikasi acne vulgaris pada remaja Kabupaten Pekalongan. Pada penelitian ini terdapat 18 Kecamatan yang dijadikan sampel yaitu Kandangserang, Paninggaran, Lebakbarang, Petungkriyono, Karanganyar, Kajen, Talun, Doro, Kesesi, Sragi, Siwalan, Wonopringgo, Kedungwuni, Karangdadap, Buaran, Tirto, Wiradesa dan Wonokerto. 


\section{Prosiding Seminar Nasional Kesehatan Lembaga Penelitian dan Pengabdian Masyarakat Universitas Muhammadiyah Pekajangan Pekalongan}

Berdasarkan data karakteristik responden pada penelitian ini total keseluruhan responden perempuan 298 responen (75,3\%) sedangkan laki-laki 98 responden (24,\%). Hal ini sesuai dengan penelitian Cristina (2013) bahwa perempuan lebih cenderung untuk melakukan pengobatan madiri untuk mengatasi gejala suatu penyakit dengan menggunkan obat tanpa resep dibandingkan laki-laki. Karakteristik umum berdasarkan usia bahwa kelompok responden terbanyak berusia 17 tahun dengan jumlah 103 responden (26,0\%). Karakteristik umum berdasarkan pendidikan sebagian besar repsponden berpendidikan SMA sebanyak 182 responden $(46,0 \%)$, secara teori semakin tinggi pendidikan yang dimiliki seseorang maka semakin baik pula tingkat pengetahuan yang dimiliki [7]. Karakteristik berdasarkan pekerjaan menunjukkan bahwa sebagian remaja masih menjadi pelajar sebanyak 273 responden (63,9\%), buruh sebesar 61 responden (15,5\%) dan tidak bekerja sebanyak 62 (10,6\%). Karakteristik berdasarkan tempat pembelian obat jerawat sebagian besar diperoleh di apotek sejumlah 240 responden $(60,6 \%)$, dilanjutkan di toko obat sebanyak 84 responden $(21,2 \%)$ dan di klinik kecantikan sebanyak 71 responden $(17,9 \%)$. Menurut [11] ditinjau dari kemudahan memperoleh produk obat banyak orang lebih memilih kenyamanan untuk membeli obat di apotek dibandingkan dengan harus mengantri lebih lama dirumah sakit maupun klinik selain itu obat-obat diapotek lebih dapat dipercaya mutu dan keasliannya sehingga apotek lebih dipilih untuk tempat pembelian obat. Berdasarkan karakteristik obat yang digunakan menunjukan sebagian besar obat yang digunakan Acnol gel $\circledast$ sebanyak 98 responden $(24,7 \%)$, Asam salisilat $\AA 16$ responden $(4,0 \%)$, Benzoil peroksida $\AA 38$ responden $(9,6 \%)$, Veril gel $\AA 30$ responden $(7,6 \%)$, Vitacid $\AA 2$ responden $(0,5 \%)$, dan menggunakan produk lain-lain. Karakteristik berdasarkan sumber informasi menunjukan bahwa sebagian besar sumber informasi dari pengalaman pribadi sebanyak 152 responden $(38,6)$, temanteman dan tetangga 24 responden $31,3 \%$ ), dan media massa 119 responden $(30,1 \%)$.

Berdasarkan hasil penelitian yang telah dilakukan di 18 Kecamatan Kabupaten Pekalongandidapatkan hasil gambaran pola pengobatan, pengetahuan dan perilaku swamedikasi acne vulgaris yang dilakukan oleh kalangan remaja.

Dapat dilihat pada Tabel 1 dapat disimpulkan bahwa gambaran pola pengobatan kalangan remaja di Kabupaten Pekalongan mengenai acne vulgaris sebagian besar responden memiliki kategori pola pengobatan yang cukup sebanyak 233 remaja dengan persentase $58,8 \%$. Berdasarkan hasil penelitian yang dilakukan di Kabupaten Pekalongan didapatkan hasil bahwa sebagian besar kalangan remaja melakukan pola pengobatan menggunakan obat-obatan yang dibeli di apotek seperti Acnol gel ${ }^{\circ}$ sebanyak 98 responden (24,7\%), Asam salisilat ${ }^{\circledR} 16$ responden $(4,0 \%)$, Benzoil peroksida $\AA 38$ responden $(9,6 \%)$, Veril gel $\AA 30$ responden $(7,6 \%)$, Vitacid $\AA 2$ responden $(0,5 \%)$, dan menggunakan produk lain-lain.Pola pengobatan yang cukup ini terjadi karena adanya terapi farmakologi swamedikasi jerawat yang dilakukan oleh sebagian besar kalangan remaja yaitu menggunakan obat-obatan seperti Benzoil peroksida, sulfur dan asam salisilat [1].

Berdasarkan pada Tabel 2 dapat dsimpulkan bahwa gambaran tingkat pengetahuan dari kalangan remaja di Kabupaten Pekalongan mengenai perilaku swamedikasi acne vulgaris sebagian besar responden memiliki kategori pengetahuan 


\section{Prosiding Seminar Nasional Kesehatan Lembaga Penelitian dan Pengabdian Masyarakat Universitas Muhammadiyah Pekajangan Pekalongan}

cukup sebanyak 254 orang dengan persentase 64,1\%, kategori baik sebanyak 106 orang dengan persentase $26,8 \%$ dan kategori kurang sebanyak 36 orang dengan persentase $9,1 \%$. Hal ini menunjukkan bahwa tingkat pengetahuan sebagian besar kalangan remaja di Kabupaten Pekalongan memiliki tingkat pengetahuan cukup yaitu $64,1 \%$.

Tingkat pengetahuan seseorang dipengaruhi oleh beberapa faktor yaitu faktor internal dan faktor eksternal. Faktor internal dapat meliputi pendidikan, pekerjaan maupun usia. Semakin tinggi pendidikan yang dimiliki seseorang maka akan semakin bertambah pengetahuan yang diperoleh. Faktor eksternal dapat meliputi informasi, lingkungan dan sosial budaya. Informasi sangat berpengaruh dikarenakan dapat meningkatkan pengetahuan seseorang terhadap suatu hal. Informasi yang benar dan tepat dapat mempengaruhi pengetahuan agar dapat dicapai mutu pengetahuan yang baik [8].

Berdasarkan Tabel 3 dapat dsimpulkan bahwa gambaran perilaku swamedikasi acne vulgaris kalangan remaja di Kabupaten Pekalongan sebagian besar responden memiliki perilaku cukup baik yaitu sejumlah 263 dengan persentase 66,4\%. Sebagian besar kalangan remaja memiliki perilaku yang cukup. Hal ini dapat terjadi karena ketika mengalami jerawat responden lebih memperhatikan kondisi fisik sehingga lebih cenderung untuk melakukan swamedikasi dengan menggunakan obat seperti Acnol gel, Asam salisilat, Benzoil peroksida, Verile gel dan Vitamin. Berdasarkan karakteristik umum pada penelitian yang telah dilakukan bahwa sebagian besar kalangan remaja menggunakan obat yang dibeli apotek. Membeli obat diapotek dapat disebabkan oleh beberapa faktor yaitu lebih terjangkau dan lebih murah daripada harus mengantri ke dokter atau klinik kecantikan [1].

Data hubungan tingkat pengetahuan terhadap pola pengobatan acne vulgaris diuji dengan dengan ji korelasi Chi square. Uji Chi square digunakan karena daya yangdiperoleh tidak normal yaitu 0,001 sesuai dengan syarat pengambilan keputusan uji normalitas mnurut sujarweni (2014) jika Sig <0,05 maka data berdisribusi tida normal, sebaliknya jika Sig >0,05 maka data berdistribusi normal. Sehingga digunakan analisis non parametrik untuk mengetahui hubungan antara pengetahuan terhadap pola pengobatan acne vulgaris.

Berdasarkan Tabel 4dapat disimpulkan bahwa dari peneletian yang telah dilakukan menunjukkan adanya hubungan antar variabel pengetahuan dengan variabel pola pengobatan. Dimana nilai signifikasi yang diperoleh menunjukan angka 0,000, sehingga dapat diketahui nilai signifikasi $<0,05$ maka terdapat hubungan antar dua variabel yaitu pengetahuan dan pola pengobatan acne vulgaris di kalangan remaja Kabupaten Pekalongan.

Berdasarkan Tabel 5dapat disimpulkan bahwa dari peneletian yang telah dilakukan menunjukkan adanya nilai signifikasi yang diperoleh adalah 0,000 , sehingga dapat diketahui nilai signifikasi <0,05 maka dapat disimpulkan bahwa terdapat hubungan antar dua variabel yaitu pola pengobata terhadap perilaku swamedikasi acne vulgaris yang dilakukan oleh kalangan remaja di Kabupaten Pekalongan. 


\section{Prosiding Seminar Nasional Kesehatan Lembaga Penelitian dan Pengabdian Masyarakat Universitas Muhammadiyah Pekajangan Pekalongan}

Berdasarkan Tabel 6dapat disimpulkan bahwa dari penelitian yang telah dlakukan menunjukan nilai signifikasi yang diperoleh adalah 0,000, sehingga dapat diketahui nilai signifikasi $<0,05$ maka dapat disimpulkan bahwa terdapat hubungan antar dua variabel yaitu tingkat pengetahuan terhadap perilaku swamedikasi acne vulgaris yang dilakukan oleh kalangan remaja di Kabupaten Pekalongan. Adanya hubungan antara tingkat pengetahuan terhadap perilaku swamedikasi dikuatkan dengan teori Lawrence green bahwa perilaku dapat dipengaruhi oleh faktor predisposisi yang mencakup pengetahuan, sikap, keyakinan dan nilai. Pengetahuan umunya datang dari pengalaman, baik pengalaman dari pendidikan maupun pengalaman dari orang lain. Selain itu pengetahuan juga datang dari pendidikan yang mencakup masalah perilaku individu maupun kelompok [10].

\section{Kesimpulan}

Bedasarkan hasil penelitian yang telah dilakukan terhadap 396 responden di 18 Kecamatan Kabupaten Pekalongan dapat dsimpulkan bahwa kategori pola pengobatan responden cukup baik dengan persentase 58,8\%, kategori tingkat pengetahuan responden cukup baik dengan persentase 64,1\%, kategori perilaku swamedikasi responden cukup baik dengan persentase $66,4 \%$, dan terdapat adanya hubungan antara tingkat pengetahuan kalangan remaja dengan pola pengobatan acne vulgaris dengan nilai signifikasi 0,000 , adanya hubungan antara pola pengobatan dengan perilaku swamedikasi acne vulgaris dengan nilai signifikasi 0,000 dan adanya hubungan antara tingkat pengetahuan dengan perilaku swamedikasi acne vulgaris dengan nilai signifikasi 0,000.

\section{Saran}

1. Bagi peneliti selanjutnya dapat mengambil sampel beberapa Kecamatan saja dari satu Kabupaten untuk mewakili populasi, karena banyaknya sampel sangat mempengaruhi keefektifan dalam waktu penelitian.

2. Bagi peneliti selanjutnya dikota yang sama dapat membandingkan antara pola pengobatan dan tingkat pengetahuan remaja di Kabupaten Pekalongan dengan remaja di Kota Pekalongan.

3. Bagi remaja diharapkan untuk secara aktif mencari informasi dalam melakukan pengobatan secara swamedikasi agar lebih memperhatikan obat yang akan digunakan.

\section{Referensi}

[1] Dipiro,J., Talbert, R.L., Yee, G., Wells,B., dan Posey, L.M., Pharmacotherapy Handbook 9th Edition, McGraw Hill Education Companies, New York, 2015.

[2] Ikhssani, A., Perbandingan Sikap dan Pengetahuan Swamedikasi Antara Mahasiswa Pendidikan Dokter Fakultas Kedokteran dan Non Fakultas Kedokteran Universitas Lampung. Skripsi. Fakultas Kedokteran Universitas Lampung Bandar Lampung, 7, 2019.

[3] Linuwih, S., Acne Vulgaris, Ilmu Penyakit Kulit dan Kelamin, Jakarta: Erlangga. Edisi 7. Hal 289, 2016. 


\section{Prosiding Seminar Nasional Kesehatan 2021 Lembaga Penelitian dan Pengabdian Masyarakat Universitas Muhammadiyah Pekajangan Pekalongan}

[4] Madelina, W, Sulistiyaningsih, 'Review: resistensi antibiotik pada terapi pengobatan jerawat, Farmaka, 16(2), pp. 105-117,2018.

[5] Muliyawan, D, Suriana, A-Z Tentang Kosmetika, PT Elex Media Koputindo Jakarta, 2013.

[6] Nursalam, Metodologi Penelitian Ilmu Keperawatan Pendekatan Praktis, Jakarta: Salemba Medika,2017.

[7] Notoatmodjo, Pendidikan dan Perilaku Kesehatan, Jakarta, PT Rineka Cipta, 2014.

[8] Partiwi, Pristianty, L,. Noorrizka, G., dan Impian, A., Pengaruh Pengetahuan Terhadap Perilaku Swamedikasi Obat Anti-Inflamasi Non Steroid Oral pada Etnis Thionghoa di Surabaya, Jurnal Farmasi Komunitas, VI. 1 No. 2,2014.

[9] Supardi, S., dan Surahman, Metodelogi Penelitian Untuk Mahasiswa Farmasi, CV. Trans Media, Jakarta Timur, 2014

[10] Triwibowo, Cecep dan Pusphandani, Mitha erlisya, Pengantar dasar ilmu kesehatan masyarakat cetakan II. Yogyakarta. Nuha Medika. 2017.

[11] Zeenot, S., Pengelolaan \& penggunakan Obat Wajib Apotek., DMEDIKA,2013. 